\title{
PHYTOSTABILIZATION OF MOSABONI COPPER MINE TAILINGS: A GREEN STEP TOWARDS WASTE MANAGEMENT
}

\author{
SHYAMSUNDAR PAL CHINA ${ }^{1 *}-$ MANAB DAS $^{2}-$ S.K. MAITI ${ }^{3}$ \\ ${ }^{1}$ Cyber Research \& Training Institute, University of Burdwan, \\ Burdwan-713101 \\ ${ }^{2}$ The Energy and Resources Institute, \\ New Delhi- 110003 \\ ${ }^{3}$ Dept. of Env Sc. and Engg., Indian School of Mines University, \\ Dhanbad- 826004 \\ (phone: +918419833136$)$ \\ *Corresponding author \\ e-mail:sizan@live.in \\ (Received $9^{\text {th }}$ Feb 2008 ; accepted $12^{\text {th }}$ May 2014)
}

\begin{abstract}
Bare metal mine tailings are prone to erosion as the very young top soils develop on unstable materials with low cohesion and also cause environmental pollution through leaching of toxic metals to surroundings. An appropriate vegetation cover may reduce the erosion and immobilize toxic metals through phytostabilization. The abandoned copper mines in Mosaboni (Jharkhand, India) left huge amount of untreated tailings containing high concentration toxic metals and became a source of metal pollutants. So, through a pot scale study an attempt was made to determine the potential of Cymbopogon citratus in phytostabilization of copper tailings with and without amendment. Although, limited plant growth was observed on pure tailings (T); addition of chicken manure (M) or soil-manure mixture (MS) caused manifold increase in plant growth. Application of $\mathrm{M}$ caused more accumulation of toxic metals in aerial parts indicating possible threat of entry of toxic metal into the food chain. However, use of MS reduced metal accumulation in plant tissue. So, in the present case, where there is no option for continuous harvesting and disposal of plant biomass in the secured landfill, phytostabilization is more appropriate than phytoextraction, and lemon grass could be used in combination with MS to stabilize bare tailings.
\end{abstract}

Keywords : Copper tailings, phytostabilization, pot experiment, heavy metal

\section{Introduction}

Mining activities such as crushing grinding, washing, smelting and all the other processes used to extract and concentrate metals generate a large amount of waste rocks and tailings. Bare tailings are very prone to erosion and often cause leaching of toxic metals from tailings to soil and water [1, 2]. Metal contaminated soil and water pose serious environmental and health problems worldwide because of bio-magnifications of toxic heavy metal in food chain [3]. The problem list also includes the loss of cultivated land, forest and the overall loss of production. [4]. These will eventually lead to loss of biodiversity, amenity \& economic wealth [5].

Excavation of contaminated soil and storing the same in engineered landfill is a common practice to manage such metal rich soil or substrate. Such technology in one hand is very costly and at the same time cause dramatical disturbence to the existing landscape [3]. These problems are may be partially solved by an emerging new technology 'Phytoremediation'. It is also receiving attention lately as the results from field trials indicate a cost savings compared to conventional treatments. The term 
'Phyto-remediation' (Phyto=plants; remediation= correct evil) is relatively new, coined in 1991. Phytoremediation is the name given to a set of technologies that use different plants for containment, destruction, or an extraction technique.

Mine spoil or tailing dumps usually have barren surfaces, with rare plants that show signs of suffering such as stunted growth, chlorosis, nacrosis and anomalous development of roots with respect to shoots [6]. But also a number of plant species endemic to metalliferous soils have been found to accumulate metals at extraordinarily high levels $(>1 \%$ and up to $10 \%)$ in contrast to normal concentrations in plants called hyperaccumulators. So, far approximately 400 metal hyper accumulators have been identified [7]. The term hyper accumulator was first used by Brooks et al., [8] in relation to plants containing more than $1000-10000 \mathrm{mg} \mathrm{kg}^{-1}$ of $\mathrm{Ni}$ in dry tissue. The idea of using plant which hyperaccumulate heavy metals for remediation of metal contaminated soil was first introduced in the 1980s [9] and in recent years this has been developed as an effective technique [10,11]. Hyper accumulator plants possess genes that regulate the amount of metals taken up from the soil by roots and deposited at other locations within the plant. The depositions vary between hyperaccumultor species. There are a number of genes contributing to the hyper accumulation trait. These genes govern processes that can increase the solubility of metals in the soil surrounding the roots [2] either by acidification of the rhizosphere through the action of plasma membrane proton pumps or by secreting ligand capable of chelating metal. As well as there are other gene codes for proteins that moves metals into root xylem. Actually plat have evolve this process to liberate essential metals from the soil but in case of soil with high concentration of toxic metals will release both essential and toxic metals. Basically the metals are introduced into xylem after passing the plasma membrane. The toxic metal when present in high concentration cross the membrane through pump and channels intended to transport essential elements.

The present study was carried out to determine the physico-chemical properties of copper tailing of Mosaboni copper-mines, comparison of growth, metal accumulation and distribution in Cymbopogon citratus grown on pure and amended tailings. Lemon grass was chosen for this experiment as it has ability to draw large quantities of water, rapid growth over the entire season and persistence for several seasons, easy establishment and also to withstand dry and wet conditions.

\section{Study area}

The Mosaboni underground $\mathrm{Cu}$-mine is located at the Singhbhum shear zone in the Eastern India, Jharkhand (Fig. 1) and has produced enormous amounts of copper along with of $\mathrm{Mo}, \mathrm{Ni}, \mathrm{Au}, \mathrm{Ag}, \mathrm{Pt}, \mathrm{Co}$ etc as byproducts. Copper ores occur as stringers and disseminations associated with host rocks quartz-chlorite-biotite schistose variants of Proteozoic age. The Singhbhum copper mines were in operation from 1850's to 1995 where complete copper refinement from mining of raw ore to smelting of refined ingot of copper along with considerable amounts of byproducts recovery was integrated on a very large scale. The deposit was exploited by underground mining formed by a series of quartz veins. Mineralization is mainly in the form of sulphides, Chalcopyrite $\left(\mathrm{CuFeS}_{2}\right)$ and pyrites are two major sulphides associated with smaller quantities of sulphides of $\mathrm{Ni}$, Co and Mo etc. Magnatite with minor amount of Ilmenite and rutile constitute the main oxide minerals. The veins are located between schist, migmatitites and granites. The tailing was collected and brought from Mosaboni during December 2004 and the same was used for pot experiment. 


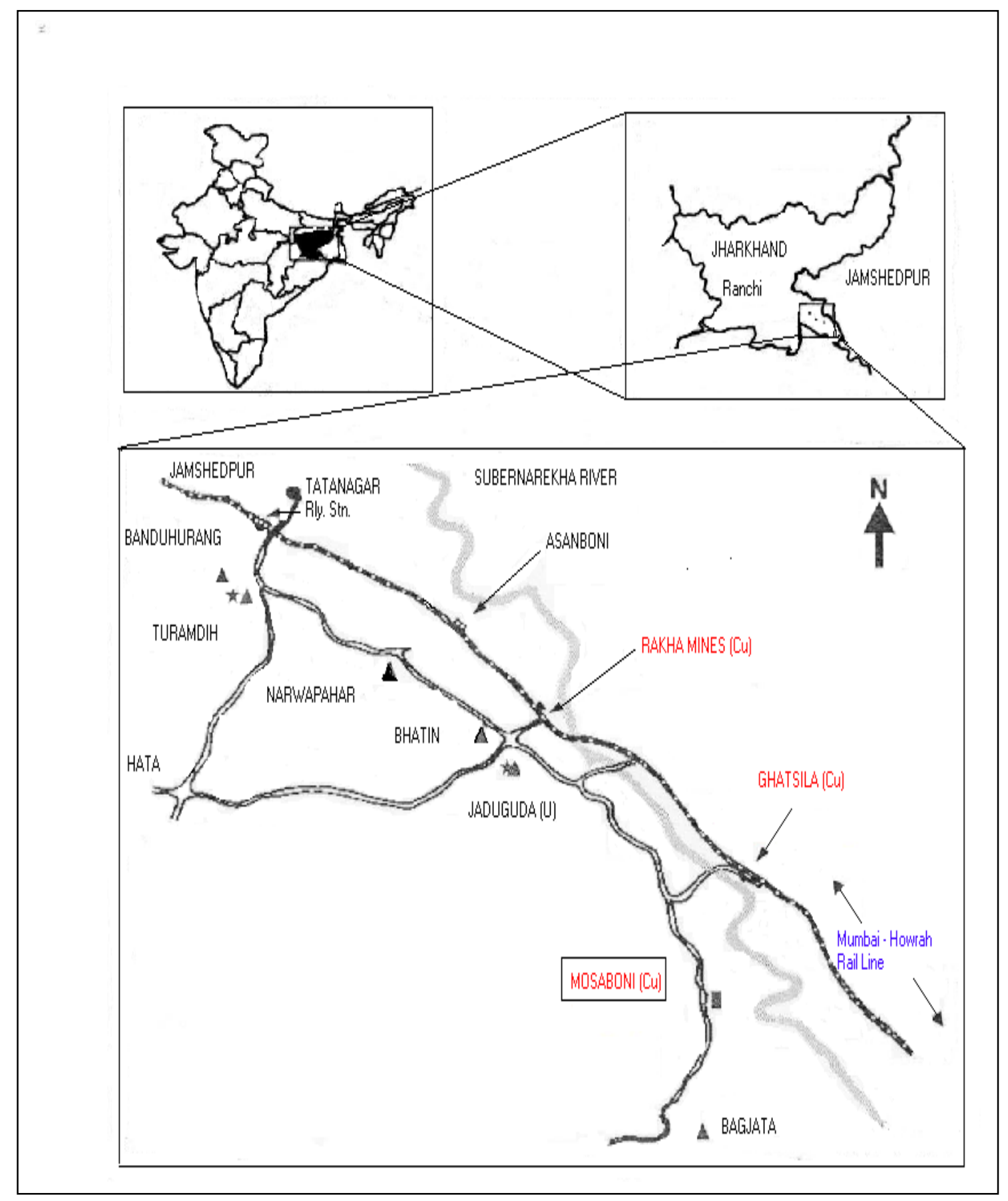

Figure 1: Location map of Mosaboni Cu-mine area

\section{Materials and methods}

\section{Pot experiment}

The pot experiment was carried out at Centre of Mining Environment, Indian School of Mines University, Dhanbad. Two different additives to copper tailings were used in the study: chicken manure and manure-soil mixtures. Soil was collected from the 
Mosaboni area (crop field soil) whereas chicken manure was bought from local farmers of Dhanbad.

Three combinations of tailing and amendments (Table 1) and the grass species Cymbopogon citratus were used for the pot experiment.

Table 1. Composition of growth medium used for pot experiment

\begin{tabular}{|l|c|c|c|}
\hline \multirow{2}{*}{ Treatment } & \multicolumn{3}{|c|}{ Composition (\%) } \\
\cline { 2 - 4 } & Tailing (T) & Chicken manure (M) & Soil (S) \\
\hline T & 100 & - & - \\
\hline TM & 97.5 & 2.5 & - \\
\hline TMS & 97.5 & 1.25 & 1.25 \\
\hline
\end{tabular}

Old clumps of Lemon grass growing on natural soil were collected and after proper washing and removal of the dried part, single clump was planted in each of the pot (3 replicates for each treatment). Experimental pots were then placed in the ISM garden under the nurture of nature.

\section{Tailings, soil and chicken manure analysis}

Tailings, soil, chicken manure and mixtures (used in pot experiment) were air-dried separately and then oven dried at $80^{\circ} \mathrm{C}$ for 2 hours and sieved through $2 \mathrm{~mm}$ mesh. A fraction of sieved samples was used for determination of $\mathrm{pH}$, electrical conductivity, organic carbon, available nitrogen, cation exchange capacity [12]. Another fraction of dried samples was processed for environmentally available [13] and bioavailable $\mathrm{Cu}, \mathrm{Ni}$ and $\mathrm{Pb}[14]$ content in samples. Metal contents in processed samples were determined by using Flame Atomic Absorption Spectrophotometer (FAAS), Avanta, GBC, Australia.

\section{Plant sample analysis}

After 6 months of growth experiment, plants were harvested carefully from each pot. The soil (tailings/sediments) loosely adhered to roots were gently shaken off and the rhizosphere soil adhering to roots were separated by hands. Individual plants were divided into two components: root and shoot, carefully washed in deionized water until visual inspection revealed that no solid particles remained adhering to the roots or shoots. Cleaned plant samplers were then oven dried at $80^{\circ} \mathrm{C}$ overnight. Dried plant samples (shoots and roots) were ground to powder form in a mixer grinder. The powdered samples were digested with concentrated $10 \mathrm{ml}$ conc. $\mathrm{HNO}_{3}$ and conc. $\mathrm{HClO}_{4}$ (5:1, v/v) as suggested by Yang et al. [15]. Metal concentrations in digests were determined by FAAS.

\section{Result and discussion}

\section{General characteristics of tailing and additives used for pot experiment}

The general properties of the tailings material are shown in Table 2. The tailing was slightly acidic in nature ( $\mathrm{pH} 5.03$ ) having low organic carbon $(0.27 \%)$ and low available nitrogen $(0.007 \%)$ content. The acidic nature of the tailing may be due to the release of 
protons produced by oxidation of sulphide minerals present in the $\mathrm{Cu}$ tailings. Low available nitrogen can be explained by the small contribution made by the organic matter (low content and low negative charge due to the acidity of the samples), as well as lack of microorganism, which make it bioavailable. The low cation exchange capacity $\left[2.63 \mathrm{c} \mathrm{mol}(+) \mathrm{Kg}^{-1}\right]$ may be due to the lack of inorganic colloids (sandy and sandy loam textures) and also of low organic carbon.

When comparing environmentally available metal (same as total metal excluding metal that bound in silicate matrix, which is not usually mobile in the environment), $\mathrm{Cu}$ (154 $\left.\mathrm{mg} \mathrm{kg}^{-1}\right)$ appeared as the most abundant heavy metal, followed by Ni (136 mg kg $\left.{ }^{-1}\right)$ and $\mathrm{Pb}\left(9.9 \mathrm{mg} \mathrm{kg}^{-1}\right)$.

The analysis of the potentially bioavailable metal fraction is probably more significant than the analysis of total or environmentally available metal, because the former allows prediction of the risk of metal uptake by plants and its mobility in the system [6, 16]. In the present study, $\mathrm{Cu}$ was found most abundant metal in the bioavailable form followed by $\mathrm{Ni}$ and $\mathrm{Pb}$, a sequence that is similar to that of environmentally available metal content in tailings. The bioavailable forms of $\mathrm{Cu}, \mathrm{Ni}$ and $\mathrm{Pb}$ in tailings contributed about $12.5 \%, 0.8 \%$ and $8 \%$ to the environmentally available fraction of these metals, respectively.

The physico-chemical properties of different additives, used for pot experiment are also summarized in the Table 2. Chicken manure was slightly alkaline in nature and having elevated level of electrolytes, high nutritional status and low heavy metal contents. Soil material had intermediate nutritional status and almost neutral $\mathrm{pH}$.

Table 2. General characteristics of Mosaboni Cu-tailings; Soil and Chicken manure

\begin{tabular}{|c|c|c|c|}
\hline Properties & Mosaboni Tailing & Natural Soil & Chicken manure \\
\hline $\mathrm{pH}$ & $5.03 \pm 0.04$ & $7.19 \pm 0.07$ & $7.45 \pm 0.1$ \\
\hline $\mathrm{EC}[\mathrm{dS} / \mathrm{m}]$ & $0.15 \pm 0.0$ & $0.25 \pm 0.02$ & $7.69 \pm 0.05$ \\
\hline $\mathrm{OC}(\%)$ & $0.27 \pm 0.02$ & $1.43 \pm 0.08$ & $17.1 \pm 0.007$ \\
\hline Available Nitrogen (\%) & $0.007 \pm 0.003$ & $0.02 \pm 0.004$ & $0.379 \pm 0.002$ \\
\hline $\mathrm{CEC}\left(\mathrm{cmol}(+) \mathrm{kg}^{-1}\right)$ & $2.63 \pm 0.03$ & $11.9 \pm 0.06$ & $60.1 \pm 0.040$ \\
\hline \multicolumn{4}{|c|}{ Env available metal $\left(\mathrm{mg} \mathrm{kg}^{-1}\right)$} \\
\hline $\mathrm{Cu}$ & $154.3 \pm 1.9$ & $25.9 \pm 0.62$ & $69.8 \pm 0.31$ \\
\hline $\mathrm{Ni}$ & $136 \pm 1.8$ & $19.7 \pm 0.23$ & $17.4 \pm 0.27$ \\
\hline $\mathrm{Pb}$ & $9.9 \pm 0.9$ & $46.3 \pm 0.63$ & $18.8 \pm 0.16$ \\
\hline \multicolumn{4}{|c|}{ DTPA available metal $\left(\mathrm{mg} \mathrm{kg}^{-1}\right)$} \\
\hline $\mathrm{Cu}$ & $19.3 \pm 0.78$ & $0.5 \pm 0.03$ & $16.9 \pm 0.37$ \\
\hline $\mathrm{Ni}$ & $1.1 \pm 0.56$ & $1.8 \pm 0.01$ & $1.6 \pm 0.02$ \\
\hline $\mathrm{Pb}$ & $0.79 \pm 0.01$ & $1.19 \pm 0.04$ & $1.0 \pm 0.02$ \\
\hline
\end{tabular}

\section{Comparision of plant biomass}

The biomass productions of lemon grass in tailing and different amended tailing are summarized in the Table 3. Use of additives like chicken manure or a mixture of soil and manure caused more biomass production compare to untreated tailings. Addition of chicken manure accounted 10 times increase in biomass production whereas tailings treated with soil-manure mixture produced about 8 times more biomass than pure tailings. In terms of number of tillers, treated tailings shown much better response than pure tailings. 
Table 3. Comparison of plant growth in different amended tailing

\begin{tabular}{|l|c|c|}
\hline \multicolumn{1}{|c|}{ Treatment } & Biomass, DW $\mathbf{~ ( g / m 2 )}$ & No. of tillers/plant \\
\hline T & $27 \pm 2$ & $2.3 \pm 0.6$ \\
\hline TM & $289 \pm 42$ & $7.3 \pm 0.6$ \\
\hline TMS & $215 \pm 26$ & $6.3 \pm 1.5$ \\
\hline
\end{tabular}

\section{Comparison of metal accumulation}

Regarding metal accumulation in root, lemon grass grown on pure tailing accumulated more $\mathrm{Cu}$ and $\mathrm{Ni}$ than the same species grown on the amended tailing. Whereas, shoot accumulation of $\mathrm{Cu}, \mathrm{Ni}$ and $\mathrm{Pb}$ in the lemon grass, grown on amended tailing found higher than pure tailings (Fig. 2).
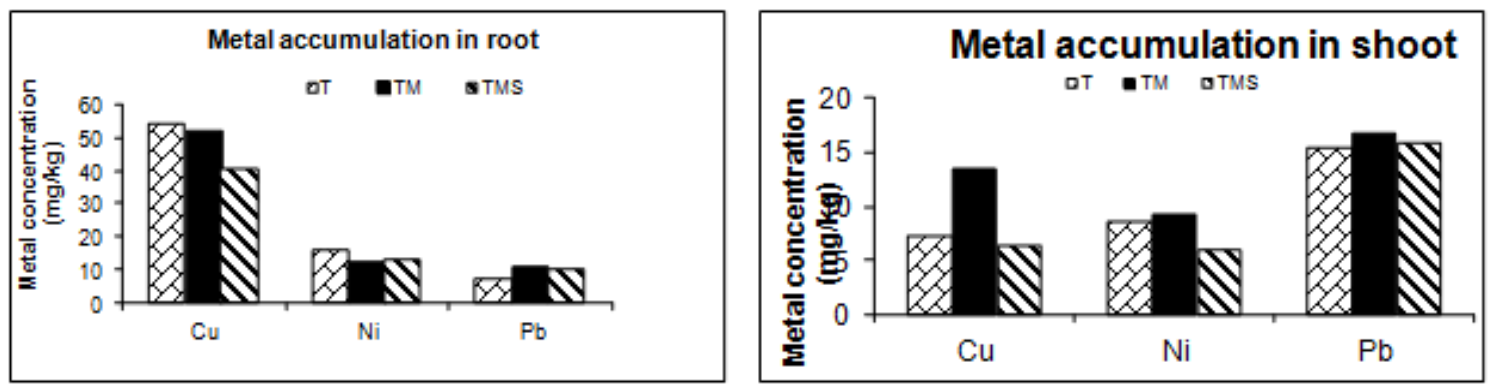

Figure 2. Metal accumulation shoot and root of lemon grass grown on pure and amended tailings.

\section{Conclusion}

Copper tailing of Mosaboni mine was found acidic in nature and had low cation exchange capacity, elevated concentration of toxic metals and low nutrient contents. The most abundant heavy metal in both environmentally available and bio-available fraction was $\mathrm{Cu}$ followed by $\mathrm{Ni}$ and $\mathrm{Pb}$. Concentration of $\mathrm{Pb}$ in both environmentallyavailable and bio-available fraction of normal soil was found higher than $\mathrm{Cu}$-tailings. In all the samples concentration of total $\mathrm{Cu}$ and $\mathrm{Ni}$ were found exceeding the toxicity threshold limit [17]. Pot experiment revealed that despite of chemical limitations; lemon grass could grow on copper tailing but with limited growth. On the other hand, use of additives like chicken manure and soil could increase the growth (in terms of biomass and no. of tillers) in many folds. Addition of only chicken manure caused increase in metal accumulation by plant shoot but the opposite trend was found in metal accumulation by plant root. While, use of a mixture of chicken manure and soil decreased metal (except $\mathrm{Pb}$ ) accumulation in both root and shoot of the lemon grass. Higher biomass production means, it would give rise to more addition of organic matter in tailing, and hence increase the moisture content which ultimately facilitate the growth of other native plants and stabilize (phytostabilization) the unstable tailings. High metal accumulation (phytoextraction) leads to removal of metals from tailing but it may results entrance of toxic metal into the food chain. So, in the present case where there is no option for continuous harvesting of plant biomass and disposal of the same in the secured dumping site, phytostabilization is more appropriate than phytoextraction, and lemon grass can be used for this purpose with addition of some additives. Use of a 
mixture of soil and chicken manure is more effective rather than only chicken manure because the former mixture results in high biomass production with lower accumulation of metals in plant's aerial parts.

\section{REFERENCES}

[1] Davies, BE. (1980): Trace element pollution. -In: Davies, B.E. (ed.) Applied Soil Trace Elements, Wiley New York.

[2] Davies, B.E. (1983): Heavy metal contamination from base metal mining and smelting: implication for man and his environment. -In: Thornton, I. (ed.) Applied Environmental Geochemistry, Academic Press.

[3] Kochian, L.V. (2000): Phytoremediation using plants to clean up soil. Agricultural research: 4-8.

[4] Wang, W.S., Shan, X.Q., Wen, B., Zhang, S.Z. (2003): Relationship between the extractable metals from soils and metals taken up by maize roots and shoots. Chemosphere 53: 525-530.

[5] Breadshaw, A.D. (1993): Understanding the fundamentals of succession. Primary succession on land. -In: Miles, J., Walton, D.H. (ed.), Blackwell, Oxford.

[6] Dinelli, E., Lombini L. (1996): Metal distribution in plants growing on copper mine spoils in Northern Apennies, Italy: the evaluation of seasonal variations. Applied Geochemistry 11: 375-385.

[7] Baker, A.J.M. (1995). Metal hyperaccumulation by plants: our present knowledge of the ecophysiological phenomenon. Will plants have a role in bioremediation? 14 th annual symposium on current topics in plant biochemistry, physiology and molecular biology. Columbia, 7-8.

[8] Brooks, R.R., Lee, J., Reeves, R.D., Jaffre, T. (1977): Detection of nickeliferous rocks by analysis of herbarium specimens of indicator plants. J Geochem Explor 7:49-57.

[9] Chaney, R.L. (1983): Plant uptake of inorganic waste constituents. -In: Land treatments of hazardous wastes. Parr, J.F., Marsh, P.B., Kla, J.M. (ed.) N J: Noyes Data Corp. Park Ridge.

[10] Salt, D.E., Blaylock, M., Kumar, P.B.A.N., Dushenkov, S., Ensley, B.D., Chet. I., Raskin, I. (1996): Phytoremediation: a novel strategy for the removal of toxic metals from the environment using plants. BioTech.: 468-474.

[11] Reeves, R.D. (2002): Metal-tolerance and metal-accumulating plants: exploration and exploitation. -In: Heavy metals and plants, 9 th New Phytologist Symposium. Philadelphia.

[12] Das, M., Maiti, S. K., (2009). Growth of Cymbopogon citratus and Vetiveria zizanioides on $\mathrm{Cu}$-mill tailings amended with chicken manure and manure-soil mixtures: A pot scale study. International Journal of Phytoremediation, vol 11, 8: 651-63.

[13] USEPA 3050B. (1996). Acid digestion of sediments, sludges, and soils. CD-ROM, Revision 2.

[14] Lopez-Sanchez, J.F., Sahuquilo, A., Rauret, G., Lachica, M., Barahona, E., Gomez, A., Ure,A.M., Muntau, H., and Quevauviller, P.H. (2000). Extraction procedures for soil analysis. In: Methodologies in Soil and Sediment Fraction Studies: Single and Sequential Extraction Procedures, pp. 28-65. (Quevauviller, P.H., Ed.). Cambridge, UK, Royal Society of Chemistry.

[15] Yang, B., Shu, W.S., Ye, J.H., Lan, C.Y., Wong, M.H. (2003): Growth and metal accumulation in vetiver and two Sesbenia species on lead/zinc mine tailings. Chemosphere 52: 1593-1600.

[16] Freitas, H., Prasad, M.N.V., Pratas, J.(2004): Plant community tolerant to trace elements growing on the degraded soils of Sao Domingos mine in the south east of Portugal: Biomagnificat implications. Enviroment International 30: 65-72. 
